\title{
Black bear recolonization patterns on human-dominated landscapes vary based on housing: New insights from spatially explicit density models.
}

EVANS, Michael J. (michael.evans@uconn.edu) ${ }^{1}$

RITTENHOUSE, Tracy A.G. (tracy.rittenhouse@uconn.edu) ${ }^{1}$

HAWLEY, Jason E. (jason.hawley@ ct.gov) ${ }^{2}$

REGO, Paul W.(paul.rego@ct.gov) ${ }^{2}$

${ }^{1}$ Wildlife and Fisheries Conservation Center, Department of Natural Resources and the Environment, University of Connecticut, 1376 Storrs Rd., Storrs, CT 06269, USA

Email: michael.evans@uconn.edu

Phone: 860-486-2327

${ }^{2}$ Connecticut Department of Energy and Environmental Protection, Wildlife Division, Sessions Woods WMA, 341 Milford St., Burlington, CT 06013, USA 
2

\section{ABSTRACT}

Housing development is often intermixed within natural land cover, creating coupled humannatural systems that benefit some species, while eliminating critical habitat for others. As carnivore populations recover and expand in North America, understanding how populations may recolonize human-dominated landscapes is an important goal for conservation. We empirically test whether a population of American black bear (Ursus americanus) recolonizing a developed landscape is responding to land cover, housing density, or the amount of intermixture between forest and housing as quantified by the Wildland Urban Interface. Housing density was the most supported spatially explicit mark-recapture model and indicated that bear density was highest among exurban housing densities. Mean estimated bear density in exurban areas (6-49 houses $/ \mathrm{km}^{2}$ ) was 0.18 individuals $/ \mathrm{km}^{2}$ compared to 0.12 individuals $/ \mathrm{km}^{2}$ in rural areas $(<6$ houses $/ \mathrm{km}^{2}$ ). Bear densities also declined to zero as development approached 50 houses $/ \mathrm{km}^{2}$. We also tested for differences in sex ratio between more and less intensely developed areas, using hybrid mixture models. Sex ratios were significantly more male-biased in areas of higher housing density. Elevated bear densities provide evidence that exurban land-use can facilitate recolonization of black bears, yet high housing density may also limit the recovery of bear populations. Explicit relationships between land-use and bear density will allow managers to anticipate future population distribution, and areas where bears and people may come into frequent contact.

Key Words conservation; exurban; land-use; recolonization; spatially explicit mark-recapture; synanthropic 


\section{Introduction}

Understanding the consequences of changing land-use patterns on ecological processes is

27 critical to the conservation of natural resources (Ricketts \& Imhoff, 2003), as urban areas are growing on average twice as fast as their human populations (Seto et al., 2011). In the United

29 States exurban development has been the fastest growing pattern of land-use (Brown et al., 2005). Frequently this form of development integrates natural land cover and housing potentially increasing habitat for wildlife (Clark et al., 2009; Theobald, 2001). This intermixing of development and natural land cover blurs traditional urban-rural distinctions, creating intermixed ecosystems (Zipperer et al. 2000). The Wildland Urban Interface (WUI) provides one way to describe these landscapes, using vegetated (i.e., little housing), intermixed (i.e., areas with where houses are located amidst natural cover), interfaced (i.e., areas where houses abut natural vegetation, and non-vegetated (i.e., houses and imperious surfaces) classifications urbanizing landscapes.

Intermixed ecosystems have led to a proliferation of synanthropic wildlife - species that exhibit positive demographic or numeric responses in the presence of people (Johnston, 2001; densities in urban landscapes (see Bateman et al., 2012 for a review). Carnivore cohabitation 
48 relying on natural resources, to exploiters (i.e., synanthropes) with positive association with 49 people (McKinney, 2006). The recovery and expansion of carnivore populations across North 50 America and Europe (Chapron et al., 2014; Linnell et al., 2001) has increased the presence of 51 carnivores within human-modified landscapes, creating a need to understand how recolonizing 52 populations respond to human activities.

53 Our goal was to understand how recolonizing wildlife populations respond to human54 modified landscapes. Here we focus on the American black bear (Ursus americanus), a 55 prominent species in urban wildlife research. Once extirpated from much of North America, 56 populations have been recolonizing the former range over the last several decades (Garshelis \& 57 Hristienko, 2006). Black bears were thought to require large amounts of natural land cover 58 including forest, shrubland, and wetland habitats (Powell et al., 1997) - and to be negatively 59 affected by human activity (Brodeur et al., 2008; Dixon et al., 2007). However, populations are 60 expanding into urban landscapes, often exploiting anthropogenic foods (Johnson et al., 2015;

61 Merkle et al., 2013; Ranglack et al., 2009). In landscapes classified as interface, bears select

62 high quality natural land cover, and portions of the home range extend into urban areas,

63 indicating urban avoidance (Baruch-Mordo et al., 2014; Johnson et al., 2015). This research has 64 occurred primarily in the western United States. However, bears are increasingly recolonizing 65 intermixed areas (Ellingwood, 2003; Evans et al., 2014) throughout the eastern US, where there are no rural areas within entire bear populations and individual home ranges.

67 The recent re-establishment of a black bear population in western Connecticut presents an opportunity quantify bear population distributions when recolonizing urbanized landscapes. While bear range in the state is composed primarily of forested land cover (i.e., National Land 70 Cover Database; Fry et al. 2011), housing density within the range are predominantly exurban, 
71 with small patches of rural and urban areas (U.S. Census, 2010), and the WUI map depicts

72 Connecticut as $72 \%$ intermixed (Fig. 2). Our first objective was to use spatially explicit mark-

73 recapture models to test competing hypotheses regarding whether bears densities vary with land

74 cover, housing density, or the amount of intermixture between forest and housing as quantified

75 by the Wildland Urban Interface. We hypothesized that both forest cover and housing density

76 influence the spatial distribution of bears, and thus predicted that the WUI would best explain

77 spatial variation in bear density.

78 Our second objective was to identify where black bear density is highest, by quantifying the 79 relationship between bear density and identified landscape classifications. We expected bear

80 densities would be highest in intermixed areas, because these landscapes contain both forest

81 cover and anthropogenic foods such as garbage and bird feeders (Greenleaf et al., 2009; Mazur

$82 \&$ Seher, 2008). Finally, we expected this relationship to differ between males and females due

83 to differences in dispersal (Costello et al., 2008; Moyer et al., 2006) and behavior at range

84 peripheries between the sexes (Beckmann \& Berger, 2003b; Sato et al., 2011). Quantifying the

85 response of expanding black bear populations to human-modified landscapes will help wildlife

86 managers and land-use planners anticipate the future patterns of bear recolonization, and plan

87 conservation strategies.

2. Methods

\subsection{Study area and sample collection}

Spatially explicit mark-recapture (SMRC) models (Gardner et al., 2009) use the locations of

91 individual detections to directly estimate population densities. We used non-invasive hair corrals

92 (Woods et al., 1999) to collect hair samples from black bears in northwest Connecticut, which

93 provided genetic material used for individual identification. Corrals consisted of two strands of 
94 barbed wire spaced at $30 \mathrm{~cm}$ and $45 \mathrm{~cm}$ off of the ground, creating an enclosure of $\sim 5 \times 5 \mathrm{~m}$. We 95 attracted bears to corrals using non-nutritional scent lures applied to log piles at the center of

96

97

corrals, and rags hung over corrals. Scent lures did not provide a food reward, minimizing the potential for bears becoming conditioned to return to corrals. We used multiple, intensive (Wilton et al., 2014) sampling grids to systematically distribute hair corrals across four study areas. Grids encompassed the entire reproductive range of black bear in western CT, and spanned the full gradient of housing densities therein (Fig. 1).

Grid cells were $2.5 \mathrm{~km}^{2}$, with one hair corral per cell, to accommodate $3-4$ corrals within an area the size of a female summer home range (approx. $30 \mathrm{~km}^{2}$, CT DEEP unpublished data). North grid consisted of 49 corrals in the northwest corner of CT, and covered $271 \mathrm{~km}^{2}$. Land cover on and around this grid was primarily mixed and deciduous forest as according to land cover maps (Fry et al. 2011), and confirmed during ground surveys, with an average housing density of $6.8 \mathrm{~km}^{-2}$. East grid had 48 corrals across $215 \mathrm{~km}^{2}$ of suburban and exurban areas of $\mathrm{CT}$, with an average housing density of $83.6 \mathrm{~km}^{-2}$. South grid was $220 \mathrm{~km}^{2}$ containing 50 corrals. This grid was located in an attempt to span the southern extent of reproductive bear range. Average housing density within South grid was $23.2 \mathrm{~km}^{-2}$. Barkhamsted grid consisted of 25 corrals over $95 \mathrm{~km}^{2}$. Barkhamsted grid was similarly forested but contained higher housing densities $\left(\right.$ mean $\left.=37.3 \mathrm{~km}^{-2}\right)$ than North grid.

Bear hair was collected over two sampling years during June - August, 2013 and 2014. We used four different scents over the course of each sampling season to increase trap novelty and minimize a behavioral response to previous detection. Within a sampling occasion, the same lure was applied at all sites. New scent lure was applied at each visit. We collected 814 hair samples in 2013 and 1226 hair samples in 2014. Hair samples were collected from corrals and 
117 stored in small, paper envelopes weekly, producing 12 sampling occasions in 2013 and 11

118 occasions in 2014. Corrals on Barkhamsted grid were only operated during 2014 and only the

119 northernmost 25 corrals were operated in South grid in 2014. All hairs deposited on a single

120 barb were considered a single sample.

121

122

123

124

125

126

127

128

129

130

131

132

133

134

135

136

137

138

\subsection{Genetic methods}

We extracted DNA from hair follicles using the InstaGene Matrix (Bio-Rad Laboratories, Hercules, CA) following the protocol of Eggert et al. (2005). We assessed restriction fragment length polymorphisms at the cytochrome b region following digestion with DdeI and ApoI to confirm species identification. We compared amplified fragment sizes to positive controls of black bear, raccoon (Procyon lotor), domestic dog (Canis familiaris), red fox (Vulpes vulpes), coyote (Canis latrans), and white-tailed deer (Odocoileus virginianus) eliminating all samples not producing a positive bear genotype.

To identify individuals we amplified extracted DNA from all bear samples at seven polymorphic microsatellite loci (G1A, G10B, G10L, G10P, G1D, G10M, G1C; Paetkau \& Strobeck, 1994, 1998). We determined individual sex by amplifying the Amelogenin gene

(Carmichael et al., 2005). We used the redesigned primer pairs of Kristensen et al. (2011) to increase genotyping efficiency using low concentration and potentially degraded DNA. All PCR reactions were performed in a UV-sterilized hood, following the multiplex genotyping protocol of Puckett et al. (2014). One well on each 96-well plate contained extracted DNA from a bear handled by CT DEEP during den visits as a positive control. Products were separated in a DNA Analyzer (ABI 3730, Applied Biosystems, Waltham, MA, USA) at the University of Missouri DNA Core Facility (Columbia, MO). We scored the size of fluorescently labeled DNA 
139 fragments against size standards (GeneScan 600 LIZ, Life Technologies, Waltham, MA, USA)

140 to generate genotype data using GENEMARKER v1.97 (Soft Genetics, State College, PA).

141 We estimated $P_{I D}$ and $P_{I D s i b s}$ (Waits et al., 2001) - the probability that two random individuals

142 and two siblings can be genetically identical at a given a set of genetic markers - in GenAlEx

143 (Peakall \& Smouse, 2006). We used the multi-tubes approach (Taberlet et al., 1996) to produce

144 consensus genotypes, amplifying and scoring up to five replicates of a sample to confirm

145 heterozygous genotypes in at least two replicates, and homozygous genotypes three times.

146 Samples were required to have consensus genotypes of at least 6 loci to be considered in further

147 analyses. We used MICRO-CHECKER v2.2.3 (Van Oosterhout et al., 2004) to test for

148 deviations from Hardy-Weinberg equilibrium due to null alleles and scoring errors. To minimize

149 the possibility for shadow effects (Mills et al., 2000) to bias density estimation, we assessed

150 genotyping error leading to misidentification of individuals using DROUPOUT v1.2 (McKelvey

$151 \&$ Schwartz, 2005). We re-genotyped individuals that differed at 3 or fewer loci, and allowed a

152 mismatch at 1 locus following this step when determining recaptures. Finally, to minimize the

153 potential for biasing density estimates by erroneously considering dependent young as

154 independent samples, we used ML-Relate (Kalinowski et al., 2006) to identify parent-offspring

155 pairs detected at a single hair corral at a single sampling occasion and treated these groups as a

156 single individual.

157

158

159

160

161

\subsection{Density modeling}

We used individual detection and re-detection data in SMRC models to estimate bear population densities around each study grid, and across all study grids in western CT. This approach considers the observed history and location of individual detections as a function of two processes; the latent density of individual activity centers, and individual detection 
162 probability. Detection probability is modeled as a function of distance between activity centers 163 and corral locations using two parameters; $g 0$, representing the probability of detection for an 164 individual with an activity center at a corral, and sigma, defining the rate of decline in detection 165 probability as individual activity centers are located farther from a corral (Fig. S1). The density 166 of activity centers are estimated as the rate parameter of a spatial poisson process, which can be 167 either constant, or variable according to spatial covariates. Models were implemented using the 168 secr package (Efford, 2012) for Program R v 3.0.2 (R Development Core Team, 2014). To fit 169 SMRC models, grids were buffered by $10 \mathrm{~km}$. This distance was determined by the 170 "suggest.buffer" function, which selects a distance beyond which further decline in detection 171 probability is negligible. We refer to these buffered extents as North, East, South and

172 Barkhamsted study areas, and the buffered extent of all corral locations as the Combined study 173 area (Fig. 2).

174 We tested hypotheses as to whether land cover, housing density, or both correspond to 175 variation in bear density by fitting SMRC models with density varying as a function of different 176 landscape classifications. In these models, different estimated rates of distribution of activity 177 centers are maximized within different areas, according to categorization. Each classification 178 represented alternative hypotheses regarding how human-modified landscapes affect the 179 distribution of bears (see Fig. 2). Classifications included forested vs. non-forested land cover 180 (COVER), housing density (HOUSE), and the Wildland-Urban Interface (WUI) classification. 181 While currently limited to the western half of CT, black bear range has been expanding south 182 following an initial recolonization in the northern part of the state (CT DEEP, unpublished data). 183 Therefore, we considered the effect of a trend in densities according to latitude (Y), both alone 184 and in addition to each of the landscape hypotheses. 
We created the COVER classification by reclassifying 30 m NLCD 2010 (Fry et al., 2011) land cover data. All forest classes, forested wetlands, and emergent wetland classes were combined into a single 'forest' class, and all other categories comprised 'non-forested' land cover. We used housing densities from 2010 census block data to derive our HOUSE classification. We aggregated census blocks into rural $\left(<6\right.$ houses $\left./ \mathrm{km}^{2}\right)$, exurban $(6-49$ houses $\left./ \mathrm{km}^{2}\right)$, suburban $\left(50-750\right.$ houses $\left./ \mathrm{km}^{2}\right)$, and urban $\left(>750\right.$ houses $\left./ \mathrm{km}^{2}\right)$ areas. These bins are used in conjunction with forest cover to define subcategories of intermix and interface areas in the Wildand-Urban Interface classification, and correspond with previous land-use definitions (; Theobald, 2001; U.S. Census Bureau, 2000). We created the WUI classification from Wildland-Urban Interface data, which includes both housing density and percent forest cover per census block, thus representing the combined effects of the COVER and DEV hypotheses. We aggregated non-WUI vegetated, intermix, interface, and developed categories. Intermixed areas have $>50 \%$ forest cover and $6-750$ houses $/ \mathrm{km}^{2}$, thus including both exurban and suburban areas. We used the maptools (Bivand \& Lewin-Koh, 2014) package to add the value of each of these spatial variables as 'habitat' covariates of points in mask objects used to fit and estimate models of variable density in secr.

We used a two-stage approach to select the appropriate detection function, and then test hypothesized relationships between bear density and landscape composition. First, we fit a set of candidate models of homogenous density, and all combinations of detection probability covariates. We considered heterogeneity in detection probability among individuals as a function of previous capture history, and among trapping locations as a function of percent forest cover within $1 \mathrm{~km}^{2}$. To account for potential differences in detection probability between sexes, and to estimate sex ratios, all detection models were fit as hybrid mixture models with sex as an 
208 individual covariate (using the "hcov" argument of the "secr.fit" function). We refer to these

209 candidate sets as detection models, which were identical for all study areas (see Table S1 in

210 supporting information). We then evaluated the addition of variable density to the top ranked

211 detection model in each study area. We considered the same candidate set of density hypotheses

212 which included our classifications of COVER, HOUSE, WUI, and a north-south trend (Y) (Table

$2131)$.

214 We evaluated model support in an information theoretic framework using Akaike's

215 Information Criterion adjusted for small sample size (AICc; Akaike, 1974; Burnham \&

216 Anderson, 2002). AICc weights $\left(\omega_{\mathrm{i}}\right)$ were used to indicate relative model support. We

217 considered models with $\omega_{\mathrm{i}}<0.10$ as unsupported, and multiple models with $\omega_{\mathrm{i}}>0.10$ as

218 competing (Burnham and Anderson, 2002). In cases in which a single model was supported, we

219 refer to this model as top-ranked. When multiple models in a candidate set were supported, we

220 used model averaging to obtain parameter estimates. We applied this approach to identify

221 supported models of bear densities in each study area and across the Combined study area, as

222 well as for males and females separately within the Combined study area. Sex ratios were

223 determined using the proportion of male and female individuals, accounting for differences in

224 detection probability, $\left(p_{m i x}\right)$ estimated from top ranked model in each study area. We tested

225 whether sex ratios differed from 50:50 in each study area, and between study areas, using a

226 likelihood ratio test between the top model, and an identical model in which the mixing

227 proportion was fixed to either 0.50 , or that of a comparison study area.

228 We used parameters from supported models from each study area to estimate black bear

229 densities as bears per $\mathrm{km}^{2}$, and applied the "region.N" function in secr, which integrates

230 estimated densities across a defined region, to estimate abundance in a given study area. For 
231 both measures we report mean estimates and standard errors. For comparison between disparate

232 landscape contexts, we report abundance and density estimates from North and East study areas.

233 We used the top ranked model from the Combined study area to identify the extent of black bear

234 range, to map the distribution of bear densities across western CT, and estimate bear abundance

235 within that range. To produce a density map, we evaluated the top ranked model across the

236 corresponding habitat mask bounded by Connecticut's northern, western, and southern borders

237 as well as the Connecticut River. We defined the southern extent of bear range in the state by the

238 latitude at which estimated bear density declined to zero.

239 3. Results

240 We genetically determined 935 hair samples to be black bear. We successfully obtained

241 individual genotypes from 734 samples. Our set of seven microsatellite loci provided sufficient

242 power to distinguish unique individuals $\left(P_{I D}=5.2 \times 10^{-10}, P_{I D s i b s}=1.5 \times 10^{-4}\right)$. Micro-Checker

243 did not indicate evidence of deviation from Hardy-Weinberg equilibrium due to null alleles or

244 genotyping error at any loci. We found 11 instances of putative parent-offspring pairs detected

245 at the same location within a sampling occasion. These detections included 17 genetic

246 individuals which we functionally treated as 6 independent individuals.

247 We detected 235 unique individuals and determined the sex of 198 bears (93 male, 105

248 female). There were no differences in number of detections among lure types used $\left(F_{3,7}=0.203\right.$,

$249 p=0.89$ ). We did not detect the same individual on multiple sampling grids within a year, but

250 detected 3 individuals (1F, 2 M) on different sampling grids between years. On the North grid

25148 of 49 sites produced bear hair, corresponding to 117 individuals. On the East grid, 62

252 individuals were detected at 37 out of 48 sites. On the Barkhamsted grid, 47 individuals were

253 detected and at 22 out of 25 sites in 2014 . Only 10 individuals were detected at 11 of the 50 
254 South grid sites. This prevented reliable estimates of abundance or density within the South 255 study area.

256 On North study area, a single detection model was supported $\left(\omega_{i}=0.999\right)$, and indicated an 257 individual behavioral response to previous detection, with $g 0$ increasing and sigma decreasing 258 following first encounter. Using this detection function, a model of homogenous bear density 259 had more support $\left(\omega_{\mathrm{i}}=0.903\right)$ than any model including variable bear density (Table 1$)$.

260 Estimated bear density for this sampling area was $0.11 \pm 8.5 \times 10^{-3}$ individuals $/ \mathrm{km}^{2}$ (Table 4), 261 resulting in estimated population sizes across the $10 \mathrm{~km}$ buffered North study area of $86.4 \pm 1.94$ 262 in 2013 and 102.2 \pm 1.94 in 2014. Estimated sex ratio was 70:30 female to male ( $p m i x=0.69 \pm$ $2630.04)$, and differed significantly from a 50:50 ratio $\left(\chi^{2}=9.95, d f=1, P=0.001\right)$.

264 On East study area, one detection model was supported $\left(\omega_{\mathrm{i}}=0.955\right)$, indicating detection 265 probability was a function of percent forest cover, with increasing $g 0$ and decreasing sigma with 266 increasing forest cover. Both the HOUSE and COVER hypotheses received AICc support 267 greater than 0.10 (Table 2). We therefore used model averaged parameter values to estimate 268 bear densities in East study area. Estimated bear density in areas of forest cover in East study 269 area was $0.24 \pm 4.5 \times 10^{-2}$ individuals $/ \mathrm{km}^{2}$ and approached zero in non-forest (Table 4).

270 Estimated population sizes across this study area were $180.1 \pm 29.9$ in 2013 and $165.2 \pm 29.9$ in 271 2014. Estimated sex ratio was 60:40 female to male ( $p m i x=0.60 \pm 0.09$ ). This sex ratio in East 272 study area differed from the estimated sex ratio in North study area $\left(\chi^{2}=96.45, d f=1, P<\right.$ $2730.001)$.

274 Within the Combined study area, the percent forest cover detection function was the most 275 supported detection model $\left(\omega_{\mathrm{i}}=0.999\right)$. Both the HOUSE and HOUSE+Y hypotheses received 276 AICc support greater than 0.10 (Table 3). Using model averaged parameters, the highest 
277 estimated densities of bear evaluated at the mean latitude in the Combined study area were in 278 places of exurban housing density $\left(0.18 \pm 2.0 \times 10^{-2}\right.$ individuals $\left./ \mathrm{km}^{2}\right)$. Estimated density in rural 279 areas was $0.12 \pm 1.9 \times 10^{-2}$ individuals $/ \mathrm{km}^{2}$. Suburban areas had an estimated density of $0.02 \pm$ $2803.8 \times 10^{-2}$ bears $/ \mathrm{km}^{2}$, and estimated bear density in urban areas was effectively zero (Table 4).

281 Estimated population sizes across the Combined study area were $411.0 \pm 29.7$ in 2013 and 415.6 $282 \pm 29.7$ in 2014. Estimated sex ratio was $66: 34$ female to male ( $p m i x=0.66 \pm 0.05)$, which was 283 significantly different from 50:50 $\left(\chi^{2}=9.95, d f=1, P=0.001\right)$. Extrapolation of this top ranked 284 model across western CT indicated bear densities were zero at the southern extent of our 285 sampling area, and the population is effectively bounded by urbanization along the Connecticut 286 River (Fig. 3). Estimated bear abundance in western CT was $427.3 \pm 29.7$.

287 After identifying housing density as the most supported landscape element corresponding to 288 variations in bear density, we fit a post hoc model of bear density as a function of continuous 289 housing density and a latitudinal trend to data from the Combined study area. This model 290 included a squared housing density predictor, to accommodate the potentially quadratic 291 relationship indicated by the results of our HOUSE model and used the top ranked detection 292 function from the Combined study area. Because bear densities in suburban and urban density 293 housing areas were zero, we truncated housing density data at 50 houses $/ \mathrm{km}^{2}$ to quantify a 294 relationship over the range of housing densities at which bears persisted. Maximum estimated 295 bear density occurred at 13.2 houses $/ \mathrm{km}^{2}\left(95 \% \mathrm{CI}=7.5-18.2\right.$ houses $/ \mathrm{km}^{2}$; Fig. 4).

296 Male and female data were too sparse to test models of variable density for each sex within 297 North and East study areas. We proceeded with sex specific model fitting for the Combined 298 study area. Females exhibited a trap-happy behavioral response $\left(\omega_{i}=0.970\right.$; Table 3$)$, whereas 299 detection probability of males was a function of percent forest cover surrounding hair corrals $\left(\omega_{\mathrm{i}}\right.$ 
$300=0.997$; Table 1). For both sexes, we found two competing models of density, as both the

301 HOUSE and HOUSE + Y hypotheses received greater than 0.10 of available AICc support. The

302 order of support was reversed between sexes. HOUSE + Y was the most supported model of

303 female density $\left(\omega_{i}=0.687\right)$ followed by HOUSE $\left(\omega_{i}=0.235\right)$, whereas among males HOUSE

304 received greater support $\left(\omega_{\mathrm{i}}=0.622\right)$ than HOUSE $+\mathrm{Y}\left(\omega_{\mathrm{i}}=0.285\right.$; Table 3$)$.

305 Model averaged estimates of female bear densities evaluated at the mean latitude of the 306 Combined study area were equal in exurban $\left(0.100 \pm 0.026\right.$ females $\left./ \mathrm{km}^{2}\right)$, and rural areas $(0.095$

$307 \pm 0.038$; Table 2). Estimated male bear densities were higher in exurban $(0.058 \pm 0.022$

308 males $\left./ \mathrm{km}^{2}\right)$, relative to rural areas $\left(0.037 \pm 0.018\right.$ males $\left./ \mathrm{km}^{2}\right)$. Estimates of male and female 309 densities in both suburban and urban housing density areas (>50 houses $/ \mathrm{km} 2)$ were effectively 0 310 (Table 4).

311 4. Discussion

312 We found strong evidence that in intermixed landscapes black bear densities vary with 313 housing density, rather than forest cover, or a measure of intermixture. Despite some similarity 314 in their categorization of our study area, we found a large gap in model support between the 315 HOUSE and WUI hypotheses in all study areas (Table 1), and thus our hypothesis that the 316 distinction between intermixed and interface areas predicting bear density was not supported. We 317 found that densities in exurban areas $\left(6-49\right.$ houses $\left./ \mathrm{km}^{2}\right)$ were elevated relative to rural and 318 undeveloped areas $\left(<6\right.$ houses $/ \mathrm{km}^{2}$ ), with peak bear density occurring at $7.5-18.2$ houses $/ \mathrm{km}^{2}$ 319 (Fig. 4). These relationships suggest expanding black bear populations may recolonize exurban 320 areas, and initially avoid more intense housing. This positive numerical response in exurban 321 areas supports the conceptualization of recolonizing black bears as urban adaptors. 
Elevated black bear densities may constitute second order habitat selection (i.e.; home ranges within the population range; Johnson, 1980) for exurban areas. Given the scale of variation in

324 land-use patterns in Connecticut relative to black bear movement capabilities, we assume all 325 areas were available to be used by the black bear population. Housing densities in Connecticut 326 change over a spatial scale within the extent of daily and summer bear movements (Dobey et al., 327 2005; Powell et al. 1997). Although we found no evidence of movements between grids within 328 sampling periods, despite small distances between grids $(\operatorname{Max}=16.5 \mathrm{~km})$, we attribute this result 329 to intentionally sampling during summer, when individuals occupy well-defined home ranges 330 (DEEP unpublished data). However, bears may move among grids during fall foraging movements to track seasonal mast production (Beeman \& Pelton, 1980), and 3 individuals were 332 detected on different grids in different years. The housing categories used to test hypotheses do 333 not represent delineations recognized by bears. Bear density certainly does not change discretely

334 between rural, exurban, and suburban areas, but our results reflect a difference in rates of black 335 bear occurrence as a function of housing density at a scale relevant to their movement 336 capabilities.

337 Our post-hoc model identified a non-linear relationship between bear density and 338 continuously measured housing density, indicating an upper limit to the amount of housing 339 tolerated by bears. Bear densities declined above 18.2 houses $/ \mathrm{km}^{2}$, falling to zero as housing 340 density reached $35-50 \mathrm{~km}^{-2}$ (Fig. 4). Although bears are regularly reported among higher 341 housing densities, our results suggest that recolonizing populations are unlikely to establish in 342 expanses of suburban housing. Bears using interface areas exhibit avoidance of highly 343 developed areas, shift to nocturnal behavior (Beckmann \& Berger, 2003a; Lyons, 2005) and 344 reduce use of urban areas when natural foods are more available (Baruch-Mordo et al., 2014). 
345 Our results help resolve positive and negative response to human-modified landscapes in the

346 literature by showing elevated bear densities in exurban areas, tolerance of suburban housing

347 densities in certain landscape contexts, and evidence as to when housing densities may preclude

348 occurrence of bears and people.

349 Our findings contribute to a growing body of research that human-modified landscapes can

350 benefit ecologically flexible species. Association with humans by large, obligate carnivores is

351 often restricted to rural areas (Bateman \& Fleming, 2012). However, large-bodied mammals are

352 able to evaluate landscapes at large spatial scales (Lidicker Jr, 1999), and long distance

353 movement capabilities enable these species to traverse hostile matrices (Gehrig \& Swihart,

354 2003). As omnivores with high learning capacity and behavioral plasticity (Gilbert, 1989; Mazur

355 \& Seher, 2008), black bears also share many of the same behavioral traits as smaller mammalian

356 synanthropes (Bateman and Fleming 2012), able to exploit novel resources (e.g.; garbage, bird

357 feeders, etc.) in human-modified landscapes. Bear densities may be elevated in exurban, relative

358 to rural, contexts because increased food availability can reduce intraspecific competition and

359 increase fecundity (Hostetler et al., 2009; Moyer et al., 2007; Mitchell \& Powell, 2007).

360 Differences between the HOUSE, WUI, and COVER landscape classifications help discern

361 the relationships between housing density, land cover, and bear densities in intermixed

362 ecosystems. The lack of support for the Wildland-Urban Interface model was surprising, as we

363 expected housing density and forest cover to be important. The primary difference between the

364 two classifications was the intermixed WUI category (see Fig. 2), which includes exurban and

365 suburban areas with at least $50 \%$ forest cover (Radeloff et al., 2005). In the Combined study

366 area, both exurban (94.2\%) and suburban (72.36\%) areas were primarily intermixed, and thus

367 stronger support for HOUSE relative to WUI indicates the housing density distinction was 
368 important. Estimated densities derived from the HOUSE model suggests that bear densities

369 differ between exurban and suburban housing densities, even within $>50 \%$ forest cover.

370 In East study area, correlation between exurban areas and high forest cover was likely

371 responsible for the model selection uncertainty between COVER and HOUSE hypotheses. The

372 majority of exurban census blocks (74.9\%) were also classified as forested. In contrast, while a

373 high portion of suburban blocks were intermixed, only $38.4 \%$ were forested. Therefore, non-

374 forested areas in the East study area contained primarily suburban and urban housing densities.

375 Thus, East study area models indicating high bear densities in forested areas were

376 indistinguishable from models indicating high bear densities in exurban areas. However,

377 forested areas in the Combined study area contained both rural and exurban areas (Fig. 2), and

378 support for the HOUSE hypothesis here, in conjunction with the lack of support for the COVER

379 hypothesis, indicating differences in bear density between rural and exurban housing densities.

380 Density is not necessarily an indicator of habitat quality (Van Horne, 1983), and black bears 381 experience both positive and negative demographic responses to human activities (Beckmann \& 382 Berger, 2003a; Beckmann \& Lackey, 2008; Hostetler et al., 2009). Urban fringes support 383 persistent male biased sex ratios, and skewed age distributions towards younger individuals 384 (Beckmann \& Berger, 2003b; Johnson et al., 2015), and we found sex ratios become more male 385 biased with increasing housing density (Fig. 3). In Connecticut, both housing density and 386 increased male dispersal from core areas during range expansion (Sato et al., 2011; Swenson et $387 a l ., 1998)$ likely contribute to these patterns. A population structure more skewed toward young 388 males can negatively impact population growth, as females drive reproduction (Clark \& 389 Eastridge, 2006; Powell et al., 1996), and males can be a significant mortality source for juvenile 
390 bears (LeCount, 1987). Sex ratios, and reproductive rates should be monitored by managers to

391 fully anticipate black bear population recolonization patterns in human-modified landscapes.

392 Use of human-modified landscapes by large mammals often leads to conflict with humans

393 (Evans et al., 2014; Kretser et al., 2009), and spatially explicit density estimates can be used to 394 anticipate the future distribution of recolonizing populations. Our top ranked Combined study 395 area model included a North-South density trend and we used the latitude at which estimated 396 bear densities reached zero to define the current southern extent of recolonization (Fig. 3).

397 Additionally, estimates of density at northern latitudes in CT $\left(0.26\right.$ bears $\left./ \mathrm{km}^{2}\right)$ were similar to 398 established black bear populations in other parts of the species' range, such as upstate New York 399 (0.2/ $\mathrm{km}^{2}$; Gardner et al., 2010), New Hampshire (0.15 - 0.25; Coster et al., 2011), and Florida $400(0.12-0.14$; Dobey et al., 2005). This result, in combination with the support for a latitudinal 401 trend, suggests that bear density may increase within central and southern latitudes in 402 Connecticut, places that already receive many conflict reports.

403 5. Conclusions

404 Our results illustrate the effect of different patterns of human landscape modification on 405 recovering black bear populations. Large carnivore abundances in North America and Europe 406 have increased despite concurrent increases in human density (Chapron et al., 2014; Linnell et $407 a l ., 2001)$. Our finding that bear densities were elevated in exurban, relative to rural areas 408 suggests that as exurban land use proliferates, high density bear populations may be expected to 409 co-occur with people. Managers should anticipate increases in human-black bear conflict 410 associated with exurban land use (Evans et al., 2014). Our results also indicate that housing 411 densities above 50 houses $/ \mathrm{km}^{2}$ may create areas that bears traverse but do not persist within 412 (Long et al., 2010). Where black bear and human populations are simultaneously expanding, 
413 there is concern that increased development will reduce available habitat for bears (Bettigole et

$414 a l ., 2014)$. Land-use planning considering conservation of carnivores should account for the

415 likelihood of transitions beyond these densities, so that population growth and stability are not 416 overestimated. 


\section{References}

Akaike, H. (1974). A new look at the statistical model identification. IEEE Transactions on Automatic Control, 19(6), 716-723. doi - 10.1109/TAC.1974.1100705

Bar-Massada, A., Radeloff, V.C., \& Stewart, S.I. (2014). Biotic and abiotic effects of human settlements in the wildland-urban interface. Bioscience, 64(5), 429-437. doi 10.1093/biosci/biu039

Baruch-Mordo, S., Wilson, K.R., Lewis, D.L., Broderick, J., Mao, J.S., \& Breck, S.W. (2014). Stochasticity in natural forage production affects use of urban areas by black bears: implications to management of human-bear conflicts. PLOS ONE, 9. doi 10.1371/journal.pone.0085122

Bateman, P. \& Fleming, P. (2012). Big city life: carnivores in urban environments. Journal of Zoology, 287, 1-23. doi - 10.1111/j.1469-7998.2011.00887.x

Beckmann, J.P. \& Berger, J. (2003a). Rapid ecological and behavioral changes in carnivores: the response of black bears (Ursus americanus) to altered food. Journal of Zoology, 261(2), 207212. doi - 10.1017/S0952836903004126

Beckmann, J.P. \& Berger, J. (2003b). Using black bears to test ideal-free distribution models experimentally. Journal of Mammalogy, 84(2), 594-606. doi - 10.1644/15451542(2003)084<0594:UBBTTI>2.0.CO;2

Beckmann, J.P. \& Lackey, C.W. (2008). Carnivores, urban landscapes, and longitudinal studies: a case history of black bears. Human-Wildlife Conflicts, 2(2), 168-174.

Beeman, L.E. \& Pelton, M.R. (1980). Seasonal foods and feeding ecology of black bears in the Smoky Mountains. Bears: Their Biology and Management, 4, 141-147. doi $10.2307 / 3872858$ 
Bettigole, C.A., Donovan, T.M., Manning, R., Austin, J., \& Long, R. (2014). Acceptability of residential development in a regional landscape: potential effects on wildlife occupancy patterns. Biological Conservation, 169, 401-409. doi - 10.1016/j.biocon.2013.07.029

Bivand, R. \& Lewin-Koh, N. (2014). Maptools: tools for reading and handling spatial objects. R package version 0.8-29. (http://cran.r-project.org/web/packages/maptools).

Brodeur, V., Ouellet, J., Courtois, R. \& Fortin, D. (2008). Habitat selection by black bears in an intensively logged boreal forest. Canadian Journal of Zoology, 86(11), 1307-1316. doi 10.1139/Z08-118

Brown, D.G., Johnson, K.M., Loveland, T.R., \& Theobald, D.M. (2005). Rural land-use trends in the conterminous United States, 1950-2000. Ecological Applications, 15, 1851-1863. doi $10.1890 / 03-5220$

Burnham, K.P. \& Anderson, D.R. (2002). Model Selection and Multi-model Inference: A Practical Information Theoretic Approach. New York: Springer.

Cardillo, M., Purvis, A., Sechrest, W., Gittleman, J.L., Bielby, J., \& Mace, G.M. (2004). Human population density and extinction risk in the world's carnivores. PLoS Biology, 2(7), e197. doi - 10.1371/journal.pbio.0020197

Carmichael, L.E., Krizan, P., Blum, S.P., \& Strobeck, C. (2005). Genotyping of pseudohermaphrodite polar bears in Nunavut and advances in DNA sexing techniques. Journal of Mammalogy, 86(1), 160-169. doi - 10.1644/15451542(2005)086<0160:GOPPBI >2.0.CO;2

Chapron, G., Kaczensky, P., Linnell, J. D. C., von Arx, M., Huber, D., Andrén, H.,... Boitani, L. (2014). Recovery of large carnivores in Europe's modern human-dominated landscapes. Science, 346(6216), 1517-1519. doi - 10.1126/science.1257553 
Clark, J.K., McChesney, R., Munroe, D.K. \& Irwin, E.G. (2009). Spatial characteristics of exurban settlement pattern in the United States. Landscape and Urban Planning, 90(3), 178188. doi - 10.1016/j.landurbplan.2008.11.002

Costello, C.M., Creel, S.R., Kalinowski, S.T., Vu, N.V. \& Quigley, H.B. (2008). Sex-biased natal dispersal and inbreeding avoidance in American black bears as revealed by spatial genetic analyses. Molecular Ecology, 17(21), 4713-4723. doi - 10.1111/j.1365294X.2008.03930.x

Coster, S.S., Kovach, A.I., Pekins, P.J., Cooper, A.B. \& Timmins, A. (2011). Genetic markrecapture population estimation in black bears and issues of scale. The Journal of Wildlife Management, 75(5), 1128-1136. doi - 10.1002/jwmg.143

DeStefano, S. \& DeGraaf, R.M. (2003). Exploring the ecology of suburban wildlife. Frontiers in Ecology and the Environment, 1(2), 95-101. doi - 10.1890/15409295(2003)001[0095:ETEOSW]2.0.CO;2

Dixon, J.D., Oli, M.K., Wooten, M.C., Eason, T.H., McCown, J.W. \& Paetkau, D. (2006). Effectiveness of a regional corridor in connecting two Florida black bear populations. Conservation Biology, 20(1), 155-162. doi - 10.1111/j.1523-1739.2005.00292.x

Dobey, S., Masters, D.V., Scheick, B.K., Clark, J.D., Pelton, M.R. \& Sunquist, M.E. (2005). Ecology of Florida Black Bears in the Okefenokee-Osceola Ecosystem. Wildlife Monographs, 158(1), 1-41. doi - 10.2193/0084-0173(2005)158[1:EOFBBI]2.0.CO;2

Efford, M. (2012). secr: spatially explicit capture-recapture models. R package version 2.3.2. (http://cran.r-project.org/web/packages/secr). 
Eggert, L.S., Maldonado, J.E. \& Fleischer, R.C. (2005). Nucleic acid isolation from ecological samples_-animal scat and other associated materials. Methods in Enzymology, 395, 73-82. doi - 10.1016/S0076-6879(05)95006-4

Ellingwood, M. (2003). Nuisance black bear habitat use and activity patterns. New Hampshire Federal Aid Grant Report W-89-R-3, Concord, NH, USA.

Evans, M.J., Hawley, J.E., Rego, P.W. \& Rittenhouse, T.A.G. (2014). Exurban land use facilitates human-black bear conflicts. The Journal of Wildlife Management, 78(8), 14771485. doi - 10.1002/jwmg.796

Fry, J.A., Xian, G., Jin, S., Dewitz, J.A., Homer, C.G., Limin, Y.,...Wickham, J.D. (2011). Completion of the 2006 national land cover database for the conterminous United States. Photogrammetric Engineering and Remote Sensing, 77(9), 858-864.

Gardner, B.J., Royle, A. \& Wegan, M.T. (2009). Hierarchical models for estimating density from DNA mark-recapture studies. Ecology, 90(4), 1106-1115. doi - 10.1890/07-2112.1

Gardner, B.J., Royle, A., Wegan, M.T., Rainbolt, R.E., \& Curtis, P.D. (2010). Estimating black bear density using DNA data from hair snares. The Journal of Wildlife Management, 90(2), 318-325. doi - 10.2193/2009-101

Garshelis D.L., \& Hristienko, H. (2006). State and provincial estimates of American black bear numbers versus assessments of population trends. Ursus, 17(1), 1-7. doi - 10.2192/15376176(2006)17[1:SAPEOA]2.0.CO;2

Gehrt, S.D., Riley, S.P. \& Cypher, B.L. (Eds.). (2010). Urban carnivores: ecology, conflict, and conservation. Baltimore, MD, USA: Johns Hopkins University Press.

Gilbert, B. (1989). Behavioral plasticity and bear-human conflicts. In M. Bromley (Ed.), Bearpeople conflicts: proceedings of a symposium on management strategies. Northwest 
Territories Department of Renewable Resources, Yellowknife, Northwest Territories, Canada.

Greenleaf, S.S., Matthews, S.M., Wright, R.G., Beecham, J.J. \& Leithead, H.M. (2009). Food habits of American black bears as a metric for direct management of human-bear conflict in Yosemite Valley, Yosemite National Park, California. Ursus, 20(2), 94-101. doi 10.2192/08GR027.1

Hansen, A.J., Knight, R.L., Marzluff, J.M., Powell, S., Brown, K., Gude, P.H. \& Jones, K. (2005). Effects of exurban development on biodiversity: patterns, mechanisms, and research needs. Ecological Applications, 15(6), 1893-1905. doi - 10.1890/05-5221

Hostetler, J.A., McCown, J.W., Garrison, E.P., Neils, A.M., Barrett, M.A., Sunquist, M.E.,...Oli, M.K. (2009). Demographic consequences of anthropogenic influences: Florida black bears in north central Florida. Biological Conservation, 142(11), 2456-2463. doi 10.1016/j.biocon.2009.05.029

Johnson, D.H. (1980). The comparison of usage and availability measurements for evaluating resource preference. Ecology, 61, 65-71. doi - 10.2307/1937156

Johnson, H.E., Breck, S.W., Baruch-Mordo, S., Lewis, D.L., Lackey, C.W., Wilson, K.R.,...Beckmann, J.P. (2015). Shifting perceptions of risk and reward: Dynamic selection for human development by black bears in the western United States. Biological Conservation, 187, 164-172. doi - 10.1016/j.biocon.2015.04.014

Johnston, R.F. (Ed.). (2001). Synanthropic birds of North America. In J.M. Marzluff, R. Bowman, \& R. Donnelly (Eds.), Avian ecology and conservation in an urbanizing world (pp. 49-67). New York: Springer. 
Kalinowski, S.T., Wagner, A.P. \& Taper, M.L. (2006). ML-RELATE: a computer program for maximum likelihood estimation of relatedness and relationship. Molecular Ecology Notes, 6(2), 576-579. doi - 10.1111/j.1471-8286.2006.01256.x

Kristensen, T.V., Faries, K.M., White Jr., D. \& Eggert, L.S. (2011). Optimized methods for multiplex genotyping analysis of hair samples for American black bears (Ursus americanus). Wildlife Biology in Practice, 7(1), 123-128. doi - 10.2461/wbp.2011.7.10

LeCount, A.L. (1987). Causes of black bear cub mortality. Bears: Their Biology and Management, 7, 75-82. doi - 10.2307/3872610

Lidicker Jr, W.Z. (1999). Responses of mammals to habitat edges: an overview. Landscape Ecology, 14(4), 333-343. doi - 10.1023/A:1008056817939

Linnell, J.D., Swenson, J.E. \& Anderson, R. (2001). Predators and people: conservation of large carnivores is possible at high human densities if management policy is favourable. Animal Conservation, 4(4), 345-349. doi - 10.1017/S1367943001001408

Long, R.A., Donovan, T.M., MacKay, P., Zielinski, W.J. \& Buzas, J.S. (2010). Predicting carnivore occurrence with noninvasive surveys and occupancy modeling. Landscape Ecology, 26(3), 327-340. doi - 10.1007/s10980-010-9547-1

Lyons, A.J. (2005). Activity patterns of urban American black bears in the San Gabriel Mountains of southern California. Ursus, 16(2), 255-262. doi - 10.2192/15376176(2005)016[0255:APOUAB]2.0.CO;2

Marzluff, J.M. \& Ewing, K. (2001). Restoration of fragmented landscapes for the conservation of birds: a general framework and specific recommendations for urbanizing landscapes. Restoration Ecology, 9(2), 280-292. doi - 10.1046/j.1526-100x.2001.009003280.x 
Mazur, R. \& Seher, V. (2008). Socially learned foraging behavior in wild black bears, Ursus americanus. Animal Behaviour, 75(4), 1503-1508. doi - 10.1016/j.anbehav.2007.10.027

McKelvey, K. \& Schwartz, M. (2005). DROPOUT: a program to identify problem loci and samples for noninvasive genetic samples in a capture-mark-recapture framework. Molecular Ecology Notes, 5(3), 716-718. doi - 10.1111/j.1471-8286.2005.01038.x

McKinney, M.L. (2006). Urbanization as a major cause of biotic homogenization. Biological Conservation, 127(3), 247-260. doi - 10.1016/j.biocon.2005.09.005

Merkle, J.A., Robinson, H.S., Krausman, P.R. \& Alaback, P. (2013). Food availability and foraging near human developments by black bears. Journal of Mammalogy, 94(2), 378-385. doi - 10.1644/12-MAMM-A-002.1

Mills, L.S., Citta, J.J., Lair, K.P., Schwartz, M.K. \& Tallmon, D.A. (2000). Estimating animal abundance using noninvasive DNA sampling: promise and pitfalls. Ecological Applications, 10(1), 283-294. doi - 10.1890/1051-0761(2000)010[0283:EAAUND]2.0.CO;2

Mitchell, M.S. \& Powell, R.A. (2007). Optimal use of resources structures home ranges and spatial distribution of black bears. Animal Behaviour, 74(2), 219-230. doi 10.1016/j.anbehav.2006.11.017

Moyer, M.A., McCown, J.W., Eason, T.H. \& Oli, M.K. (2006). Does genetic relatedness influence space use pattern? A test on Florida black bears. Journal of Mammalogy, 87(2), 255-261. doi - 10.1644/05-MAMM-A-192R1.1

Moyer, M.A., McCown, J.W. \& Oli, M.K. (2007). Factors influencing home-range size of female Florida black bears. Journal of Mammalogy, 88(2), 468-476. doi - 10.1644/06-MAMMA-165R1.1

Paetkau, D. \& Strobeck, C. (1994). Microsatellite analysis of genetic variation in black bear populations. Molecular Ecology, 3(5), 489-495. doi - 10.1111/j.1365-294X.1994.tb00127.x 
Paetkau, D. \& Strobeck, C. (1998). Ecological genetic studies of bears using microsatellite analysis. Ursus, 10, 299-306.

Peakall, R. \& Smouse, P.E. (2006). GENALEX 6: genetic analysis in Excel. Population genetic software for teaching and research. Molecular Ecology Notes, 6(1), 288-295. doi 10.1111/j.1471-8286.2005.01155.x

Powell, R.A., Zimmerman, J.W. \& Seaman, D.E. (1997). Ecology and behaviour of North American black bears: home ranges, habitat, and social organization. New York: Springer.

Powell, R.A., Zimmerman, J.W., Seaman, D.E. \& Gilliam, J.F. (1996). Demographic analyses of a hunted black bear population with access to a refuge. Conservation Biology, 10(1), 224234. doi - 10.1046/j.1523-1739.1996.10010224.x

Puckett, E.E., Kristensen, T.V., Wilton, C.M., Lyda, S.B., Noyce, K.V., Holahan, P.M.,...White, D. (2014). Influence of drift and admixture on population structure of American black bears (Ursus americanus) in the Central Interior Highlands, USA, 50 years after translocation. Molecular Ecology, 23(10), 2414-2427. doi - 10.1111/mec.12748

R Development Core Team (2014). R: A language and environmental for statistical computing version 3.0.2. R Foundation for Statistical Computing (http://www.R-project.org/)

Radeloff, V.C., Hammer, R.B., Stewart, S.I., Fried, J.S., Holcomb, S.S. \& McKeefry, J.F. (2005). The wildland-urban interface in the United States. Ecological Applications, 15(3), 799-805. doi - 10.1890/04-1413

Ranglack, D., Signor, K., Bunnell, K. \& Shivik, J. (2009). Black bear activity and visitation patterns at human food sources in Utah. In J.R. Boulanger (Ed.), Proceedings of the $13^{\text {th }}$ Wildlife Damage Management Conferences (Paper 144). 
Ricketts, T., \& Imhoff, M. (2003). Biodiversity, urban areas, and agriculture: Locating priority ecoregions for conservation. Conservation Ecology, 8(2), 1 (http://www.consecol.org/vol8/iss2/art1)

Sato, Y., Itoh, T., Mori, Y., Satoh, Y.\& Mano, T. (2011). Dispersal of male bears into peripheral habitats inferred from mtDNA haplotypes. Ursus, 22(2), 120-132. doi - 10.2192/URSUS-D$10-00037.1$

Seto, K.C., Fragkias, M., Guneralp, B. \& Reilly, M.K. (2011). A meta-analysis of global urban land expansion. PLoS ONE, 6(8), e23777. doi - 10.1371/journal.pone.0023777

Swenson, J.E., Sandegren, F. \& SO-Derberg, A. (1998). Geographic expansion of an increasing brown bear population: evidence for presaturation dispersal. Journal of Animal Ecology, 67(5), 819-826. doi - 10.1046/j.1365-2656.1998.00248.x

Taberlet, P., Griffin, S., Goossens, B., Questiau, S., Manceau, V., Escaravage, N.,...Bouvet, J. (1996). Reliable genotyping of samples with very low DNA quantities using PCR. Nucleic Acids Research, 24(16), 3189-3194. doi - 10.1093/nar/24.16.3189

Theobald, D.M. (2004). Placing exurban land-use change in a human modification framework. Frontiers in Ecology and the Environment, 2(3), 139-144. doi - 10.1890/15409295(2004)002[0139:PELCIA]2.0.CO;2

Van Horne, B. (1983). Density as a misleading indicator of habitat quality. The Journal of Wildlife Management, 47(4), 893-901. doi - 10.2307/3808148

Van Oosterhout, C., Hutchinson, W.F., Wills, D.P. \& Shipley, P. (2004). MICRO-CHECKER: software for identifying and correcting genotyping errors in microsatellite data. Molecular Ecology Notes, 4(3), 535-538. doi - 10.1111/j.1471-8286.2004.00684.x 
Waite, T.A., Chhangani, A.K., Campbell, L.G., Rajpurohit, L.S. \& Mohnot, S.M. (2007). Sanctuary in the city: urban monkeys buffered against catastrophic die-off during ENSOrelated drought. EcoHealth, 4(3), 278-286. doi - 10.1007/s10393-007-0112-6

Waits, L.P., Luikart, G. \& Taberlet, P. (2001). Estimating the probability of identity among genotypes in natural populations: cautions and guidelines. Molecular Ecology, 10(1), 249256. doi - 10.1046/j.1365-294X.2001.01185.x

Wilton, C.M., Puckett, E.E., Beringer, J., Gardner, B., Eggert, L.S. \& Belant, J.L. (2014). Trap array configuration influences estimates and precision of black bear density and abundance. PLoS ONE, 9(10), e111257. doi - 10.1371/journal.pone.0111257

Woods, J.G., Paetkau, D., Lewis, D., McLellan, B.N., Proctor, M. \& Strobeck, C. (1999). Genetic tagging of free-ranging black and brown bears. Wildlife Society Bulletin, 27(3), 616637. http://www.jstor.org/stable/3784082

Zipperer, W.C., Wu, J., Pouyat, R.V.\& Pickett, S.T. (2000). The application of ecological principles to urban and urbanizing landscapes. Ecological Applications, 10(3), 685-688. doi 10.1890/1051-0761(2000)010[0685:TAOEPT]2.0.CO 


\section{Tables}

Table 1. Model selection results for spatial mark-recapture models fit to detection data from Combined study area in northwest Connecticut 2013 - 2014. The top ranked detection model was identified first, and subsequently used in all models of variable bear density. Covariates of detection included individual sex (Sex), a behavioral response to prior detection (b), and percent forest cover at a sampling site (Forest).

\begin{tabular}{|c|c|c|c|c|c|}
\hline & Hypothesized Bear Density & Detection Model & $\mathrm{AICc}$ & $\Delta \mathrm{AICc}$ & $\omega_{\mathrm{i}}$ \\
\hline \multicolumn{6}{|c|}{ Combined Study Area } \\
\hline \multirow{10}{*}{ 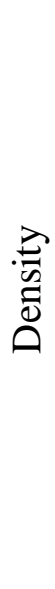 } & North-South Trend \& Different in Rural, Low, and Med/High & & & & \\
\hline & Development & $\mathrm{g} 0[$ Sex + Forest $], \sigma[$ Sex + Forest $]$ & 3817.23 & 0.00 & 0.736 \\
\hline & Different in Rural, Low, and Med/High Development & $\mathrm{g} 0[$ Sex + Forest $], \sigma[$ Sex + Forest $]$ & 3819.37 & 2.13 & 0.253 \\
\hline & $\begin{array}{l}\text { North-South Trend \& Different in Natural, Intermixed, } \\
\text { Interface and Develoned Land Use }\end{array}$ & $\mathrm{g} 0[$ Sex + Forest $] \sigma[$ Sex + Forest $]$ & 382727 & 1004 & 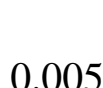 \\
\hline & Different in Natural, Intermixed, Interface, and Developed & & & & \\
\hline & Land Use & $\mathrm{g} 0[$ Sex + Forest $], \sigma[$ Sex + Forest $]$ & 3827.27 & 10.04 & 0.005 \\
\hline & North-South Trend & $\mathrm{g} 0[$ Sex + Forest $], \sigma[$ Sex + Forest $]$ & 3831.40 & 14.17 & 0.001 \\
\hline & Homogenous Density & $\mathrm{g} 0[$ Sex + Forest $], \sigma[$ Sex + Forest $]$ & 3853.13 & 35.89 & 0.000 \\
\hline & Difference between forest vs. non-forest & $\mathrm{g} 0[$ Sex + Forest $], \sigma[$ Sex + Forest $]$ & 3835.05 & 17.81 & 0.000 \\
\hline & North-South Trend \& Difference between forest vs. non-forest & $\mathrm{g} 0[$ Sex + Forest $], \sigma[$ Sex + Forest $]$ & 3833.62 & 16.39 & 0.000 \\
\hline \multirow{9}{*}{ 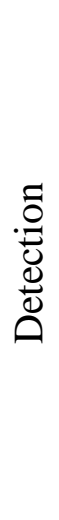 } & Homogenous & $\mathrm{g} 0[$ Sex + Forest $], \sigma[$ Sex + Forest $]$ & 3853.13 & 0.00 & 1.000 \\
\hline & Homogenous & $\mathrm{g} 0[\mathrm{Sex}+\mathrm{b}], \sigma[\mathrm{Sex}+\mathrm{b}]$ & 3885.92 & 32.80 & 0.000 \\
\hline & Homogenous & $\mathrm{g} 0[\mathrm{Sex}+$ Forest $], \sigma[\mathrm{Sex}+\mathrm{b}]$ & 3893.65 & 40.53 & 0.000 \\
\hline & Homogenous & $\mathrm{g} 0[], \sigma[\mathrm{Sex}+\mathrm{b}]$ & 3901.67 & 48.54 & 0.000 \\
\hline & Homogenous & $\mathrm{g} 0[$ Sex + Forest $], \sigma[]$ & 3924.20 & 71.08 & 0.000 \\
\hline & Homogenous & $\mathrm{g} 0[\mathrm{Sex}+\mathrm{b}], \sigma[]$ & 3932.26 & 79.14 & 0.000 \\
\hline & Homogenous & $\mathrm{g} 0[], \sigma[]$ & 3933.04 & 79.92 & 0.000 \\
\hline & Homogenous & $\mathrm{g} 0[], \sigma[\mathrm{Sex}+$ Forest $]$ & 3970.43 & 117.30 & 0.000 \\
\hline & Homogenous & $\mathrm{g} 0[\mathrm{Sex}+\mathrm{b}], \sigma[\mathrm{Sex}+$ Forest $]$ & 3971.81 & 118.69 & 0.000 \\
\hline
\end{tabular}


Table 2. Model selection results for spatial mark-recapture models fit to detection data collected 2013 - 2014 from East study area in northwest Connecticut. The top ranked detection model was identified first, and subsequently used in all models of variable bear density. Covariates of detection included individual sex (Sex), a behavioral response to prior detection (b), and percent forest cover at a sampling site (Forest).

\begin{tabular}{|c|c|c|c|c|c|}
\hline & Hypothesized Bear Density & Detection Model & $\mathrm{AICc}$ & $\triangle \mathrm{AICc}$ & $\omega_{\mathrm{i}}$ \\
\hline \multicolumn{6}{|c|}{ East Study Area } \\
\hline \multirow{10}{*}{ 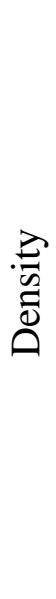 } & North-South Trend \& Difference between forest vs. non-forest & $\mathrm{g} 0[$ Sex + Forest $], \sigma[$ Sex + Forest $]$ & 967.98 & 0.00 & 0.567 \\
\hline & North-South Trend \& Different in Rural, Low, and Med/High & & & & \\
\hline & Development & $\mathrm{g} 0[$ Sex + Forest $], \sigma[$ Sex + Forest $]$ & 969.75 & 1.77 & 0.234 \\
\hline & North-South Trend & $\mathrm{g} 0[$ Sex + Forest $], \sigma[$ Sex + Forest $]$ & 971.06 & 3.08 & 0.121 \\
\hline & $\begin{array}{l}\text { North-South Trend \& Different in Natural, Intermixed, } \\
\text { Interface, and Developed Land Use }\end{array}$ & $\mathrm{g} 0[$ Sex + Forest $], \sigma[$ Sex + Forest $]$ & 972.31 & 4.33 & 0.065 \\
\hline & Difference between forest vs. non-forest & $\mathrm{g} 0[$ Sex + Forest $], \sigma[$ Sex + Forest $]$ & 975.70 & 7.72 & 0.012 \\
\hline & Different in Rural, Low, and Med/High Development & $\mathrm{g} 0[$ Sex + Forest $], \sigma[$ Sex + Forest $]$ & 976.11 & 8.13 & 0.010 \\
\hline & Different in Natural, Intermixed, Interface, and Developed & & & & \\
\hline & Land Use & $\mathrm{g} 0[$ Sex + Forest $], \sigma[$ Sex + Forest $]$ & 978.00 & 10.03 & 0.004 \\
\hline & Homogenous Density & $\mathrm{g} 0[$ Sex + Forest $], \sigma[$ Sex + Forest $]$ & 978.36 & 10.38 & 0.003 \\
\hline \multirow{9}{*}{ 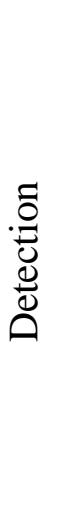 } & Homogenous & $\mathrm{g} 0[$ Sex + Forest $], \sigma[$ Sex + Forest $]$ & 978.36 & 0.00 & 0.942 \\
\hline & Homogenous & $\mathrm{g} 0[$ Sex + Forest $], \sigma[]$ & 985.02 & 6.66 & 0.034 \\
\hline & Homogenous & $\mathrm{g} 0[\mathrm{Sex}+$ Forest $], \sigma[\mathrm{Sex}+\mathrm{b}]$ & 987.34 & 8.98 & 0.011 \\
\hline & Homogenous & $\mathrm{g} 0[], \sigma[$ Sex + Forest $]$ & 994.45 & 16.09 & 0.000 \\
\hline & Homogenous & $\mathrm{g} 0[\mathrm{Sex}+\mathrm{b}], \sigma[\mathrm{Sex}+$ Forest $]$ & 996.02 & 17.66 & 0.000 \\
\hline & Homogenous & $\mathrm{g}[], \sigma[]$ & 1002.74 & 24.38 & 0.000 \\
\hline & Homogenous & $\mathrm{g} 0[], \sigma[\mathrm{Sex}+\mathrm{b}]$ & 1004.50 & 26.14 & 0.000 \\
\hline & Homogenous & $\mathrm{g} 0[\mathrm{Sex}+\mathrm{b}], \sigma[]$ & 1004.57 & 26.21 & 0.000 \\
\hline & Homogenous & $\mathrm{g} 0[\mathrm{Sex}+\mathrm{b}], \sigma[\mathrm{Sex}+\mathrm{b}]$ & 1004.79 & 26.43 & 0.000 \\
\hline
\end{tabular}


Table 3. Model selection results for spatial mark-recapture models fit to detection data collected 2013 - 2014 from North study area in northwest Connecticut. The top ranked detection model was identified first, and subsequently used in all models of variable bear density. Covariates of detection included individual sex (Sex), a behavioral response to prior detection (b), and percent forest cover at a sampling site (Forest).

\begin{tabular}{|c|c|c|c|c|c|}
\hline & Hypothesized Bear Density & Detection Model & $\mathrm{AICc}$ & $\Delta \mathrm{AICc}$ & $\omega_{\mathbf{i}}$ \\
\hline \multicolumn{6}{|c|}{ North Study Area } \\
\hline \multirow{8}{*}{ 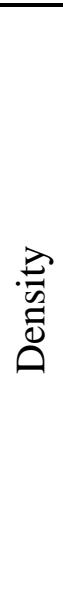 } & Homogenous & $\mathrm{g} 0[\mathrm{Sex}+\mathrm{b}], \sigma[\mathrm{Sex}+\mathrm{b}]$ & 2718.39 & 0.00 & 0.903 \\
\hline & North-South Trend & $\mathrm{g} 0[\mathrm{Sex}+\mathrm{b}], \sigma[\mathrm{Sex}+\mathrm{b}]$ & 2739.24 & 20.85 & 0.000 \\
\hline & North-South Trend \& Difference between forest vs. non-forest & $\mathrm{g} 0[\mathrm{Sex}+\mathrm{b}], \sigma[\mathrm{Sex}+\mathrm{b}]$ & 2722.85 & 4.46 & 0.097 \\
\hline & Different in forest vs. non-forest & $\mathrm{g} 0[\mathrm{Sex}+\mathrm{b}], \sigma[\mathrm{Sex}+\mathrm{b}]$ & 2740.77 & 22.39 & $<0.001$ \\
\hline & Different in Rural, Low, and Med/High Development & $\mathrm{g} 0[\mathrm{Sex}+\mathrm{b}], \sigma[\mathrm{Sex}+\mathrm{b}]$ & 2740.97 & 22.59 & $<0.001$ \\
\hline & $\begin{array}{l}\text { Different in Natural, Intermixed, Interface, and Developed } \\
\text { Land Use }\end{array}$ & $\mathrm{g} 0[\mathrm{Sex}+\mathrm{b}], \sigma[\mathrm{Sex}+\mathrm{b}]$ & 2763.29 & 44.90 & $<0.001$ \\
\hline & $\begin{array}{l}\text { North-South Trend \& Different in Rural, Low, and Med/High } \\
\text { Development }\end{array}$ & $\mathrm{g} 0[\mathrm{Sex}+\mathrm{b}], \sigma[\mathrm{Sex}+\mathrm{b}]$ & 2765.44 & 47.05 & $<0.001$ \\
\hline & $\begin{array}{l}\text { North-South Trend \& Different in Natural, Intermixed, } \\
\text { Interface, and Developed Land Use }\end{array}$ & $\mathrm{g} 0[\mathrm{Sex}+\mathrm{b}], \sigma[\mathrm{Sex}+\mathrm{b}]$ & 2773.00 & 54.61 & $<0.001$ \\
\hline \multirow{9}{*}{ 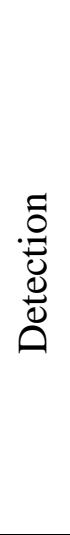 } & Homogenous & $\mathrm{g} 0[\mathrm{Sex}+\mathrm{b}], \sigma[\mathrm{Sex}+\mathrm{b}]$ & 2718.39 & 0.00 & 1.000 \\
\hline & Homogenous & $\mathrm{g} 0[], \sigma[\mathrm{Sex}+\mathrm{b}]$ & 2738.25 & 19.86 & $<0.001$ \\
\hline & Homogenous & $\mathrm{g} 0[\mathrm{Sex}+$ Forest $], \sigma[\mathrm{Sex}+\mathrm{b}]$ & 2740.36 & 21.97 & $<0.001$ \\
\hline & Homogenous & $\mathrm{g} 0[$ Sex + Forest $], \sigma[$ Sex + Forest $]$ & 2757.98 & 39.60 & $<0.001$ \\
\hline & Homogenous & $\mathrm{g} 0[], \sigma[$ Sex+Forest $]$ & 2760.32 & 41.93 & $<0.001$ \\
\hline & Homogenous & $\mathrm{g} 0[\mathrm{~b}], \sigma[\mathrm{Sex}+$ Forest $]$ & 2762.32 & 43.93 & $<0.001$ \\
\hline & Homogenous & $\mathrm{g} 0[], \sigma[]$ & 2764.35 & 45.96 & $<0.001$ \\
\hline & Homogenous & $\mathrm{g} 0[$ Sex + Forest $], \sigma[]$ & 2764.48 & 46.10 & $<0.001$ \\
\hline & Homogenous & $\mathrm{g} 0[\mathrm{Sex}+\mathrm{b}], \sigma[]$ & 2766.10 & 47.72 & $<0.001$ \\
\hline
\end{tabular}


Table 4 Estimated values, standard error and t-values for paramaters included in top ranked spatial mark-recapture models of black bear density (individuals $/ \mathrm{km}^{2}$ ) on North, East, and the Combined study areas.

\begin{tabular}{|c|c|c|c|c|}
\hline & Density Covariate $^{\mathrm{a}}$ & $\beta^{\mathrm{b}}$ & Std. Error & $t$-value \\
\hline \multicolumn{5}{|c|}{ Combined study area } \\
\hline \multirow{5}{*}{ 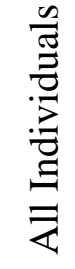 } & Density: Rural & 0.125 & 0.019 & 6.579 \\
\hline & Density: Exurban & 0.182 & 0.020 & 9.100 \\
\hline & Density: Suburban & 0.023 & 0.049 & 0.478 \\
\hline & Density: Urban & 0.000 & & \\
\hline & Latitude & 0.103 & 0.016 & 6.510 \\
\hline \multirow{4}{*}{ 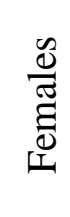 } & Density: Rural & 0.100 & 0.026 & 3.825 \\
\hline & Density: Exurban & 0.095 & 0.038 & 2.452 \\
\hline & Density: Suburban & 0.000 & - & - \\
\hline & Latitude & $-3.99 \mathrm{E}-05$ & & \\
\hline \multirow{4}{*}{$\frac{\tilde{0}}{\tilde{w}^{\frac{\pi}{\Sigma}}}$} & Density: Rural & 0.037 & 0.018 & 1.979 \\
\hline & Density: Exurban & 0.058 & 0.022 & 2.607 \\
\hline & Density: Suburban & 0.000 & - & - \\
\hline & Latitude & 7.54E-05 & $1.01 \mathrm{E}-04$ & 0.747 \\
\hline
\end{tabular}

East Study Area

\begin{tabular}{lrrr} 
Density: Forest & 0.246 & 0.045 & 5.467 \\
Density: Non-Forest & $8.86 \mathrm{E}-11$ & $1.81 \mathrm{E}-11$ & 4.899 \\
Latitude & 0.037 & 0.017 & 2.121 \\
\hline
\end{tabular}

North Study Area

\begin{tabular}{lrrr} 
Density & 0.110 & 0.008 & 12.968 \\
\hline
\end{tabular}

${ }^{\mathrm{a}}$ Density modeled as function of spatial covariates using identity link.

${ }^{\mathrm{b}} \beta$ parameter equivalent to density estimate in land-use/land cover categories. 


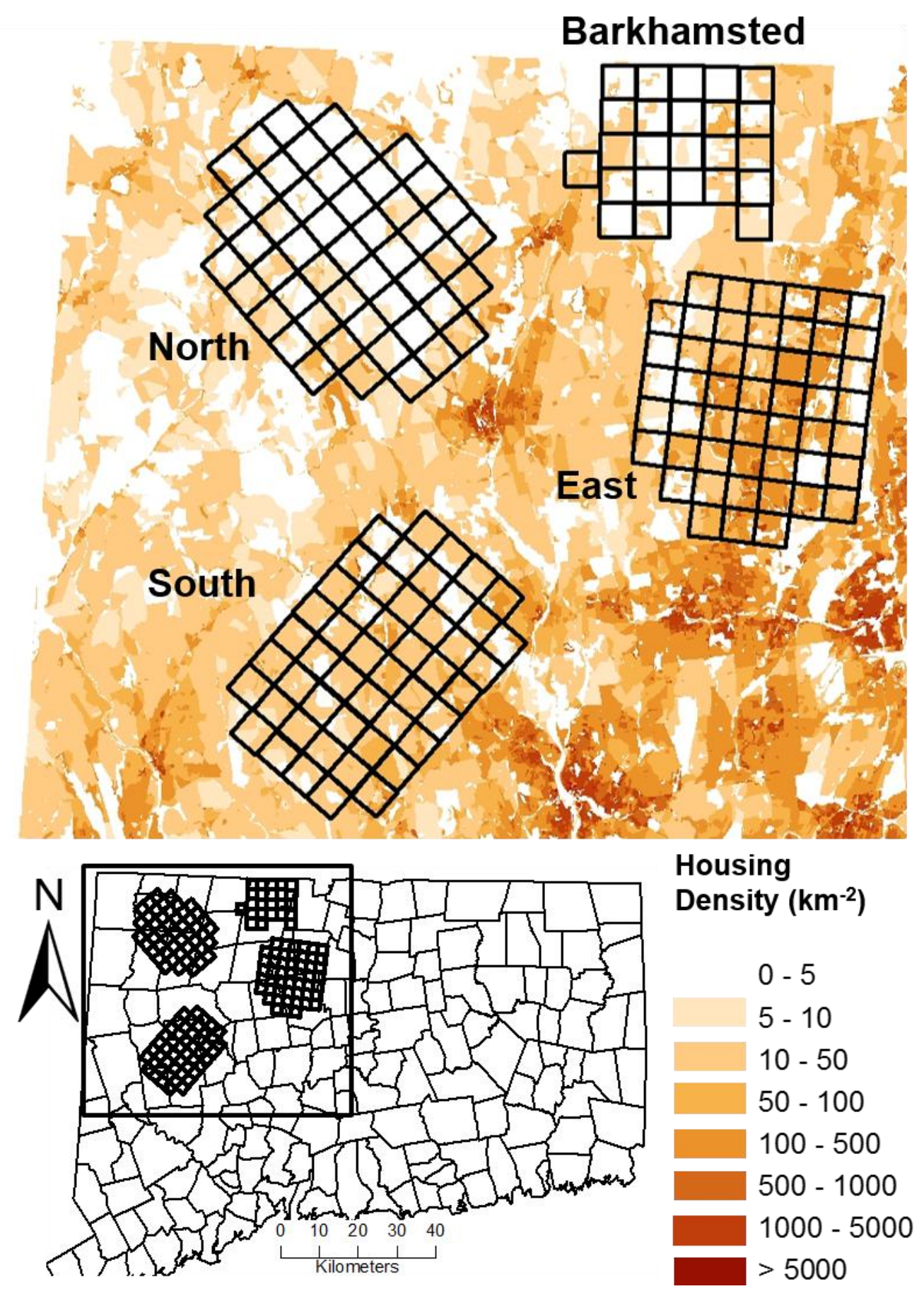

Fig.1 Placement of sampling grids across western Connecticut spans urban to rural housing density. Grids encompassed the majority of the area in the state where adult females live with cubs, as determined from public sighting reports to Department of Energy and Environmental Protection. Grids also cover the full range of housing densities found in CT in non-urban areas. 


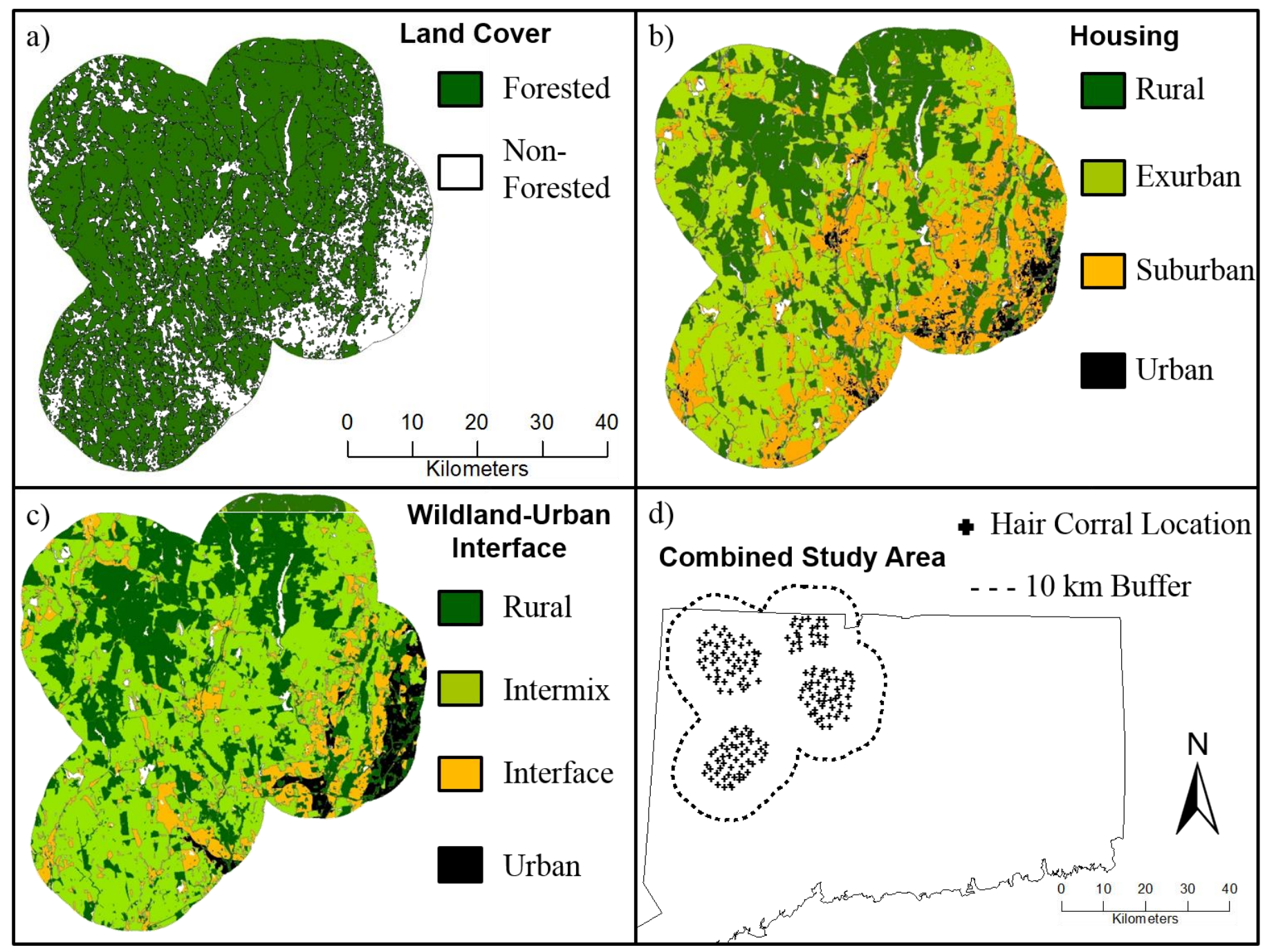

Fig. 2 Landscape classifications representing hypothesized relationships between (a) land cover, (b) housing density, and (c) wildland-urban interface categories and variation in black bear density within the (d) Combined Study Area in northwest Connecticut, USA. Landscapes were used as spatial covariates of density in spatially explicit mark-recapture models. The rate of a non-constant spatial poisson process representing rate of black bear activity centers varied between categories within a classification. 


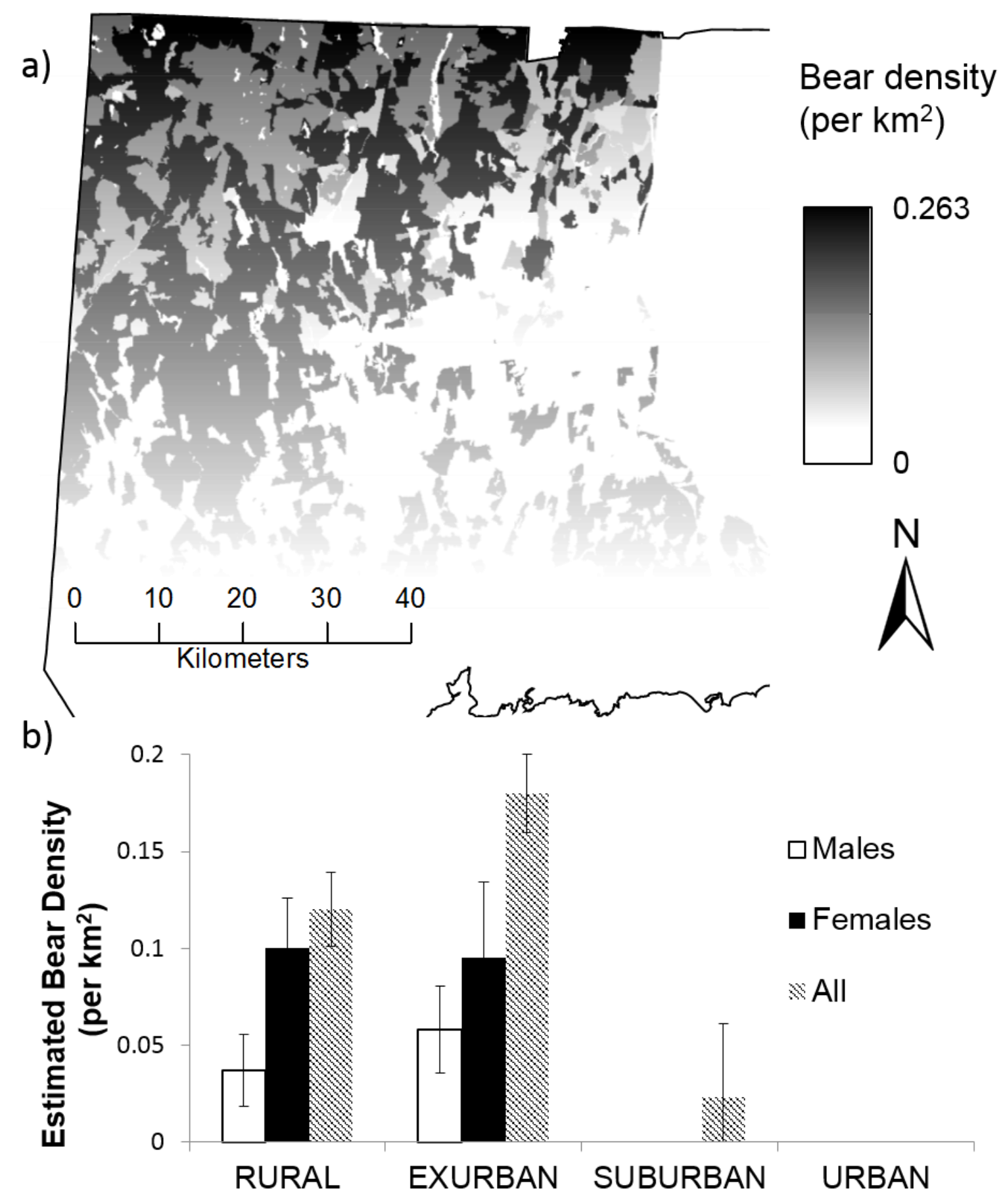

Fig. 3 Estimated black bear densities in western Connecticut. (a) Density estimated using the top ranked model of all individuals from the Combined study area across an area bounded by Connecticut's northern and western state boundaries, the Connecticut River and the southern latitude at which bear density declined to zero. (b) Mean bear density in rural $\left(<6\right.$ houses $\left./ \mathrm{km}^{2}\right)$, exurban $\left(6-49\right.$ houses $\left./ \mathrm{km}^{2}\right)$, suburban $\left(50-750\right.$ houses $\left./ \mathrm{km}^{2}\right)$, and urban $\left(>750\right.$ houses $\left./ \mathrm{km}^{2}\right)$ housing categories estimated by top-ranked models of all individuals, males, and females. Estimated values are at the average scaled latitude (0) for the Combined study area, with standard error bars shown. 


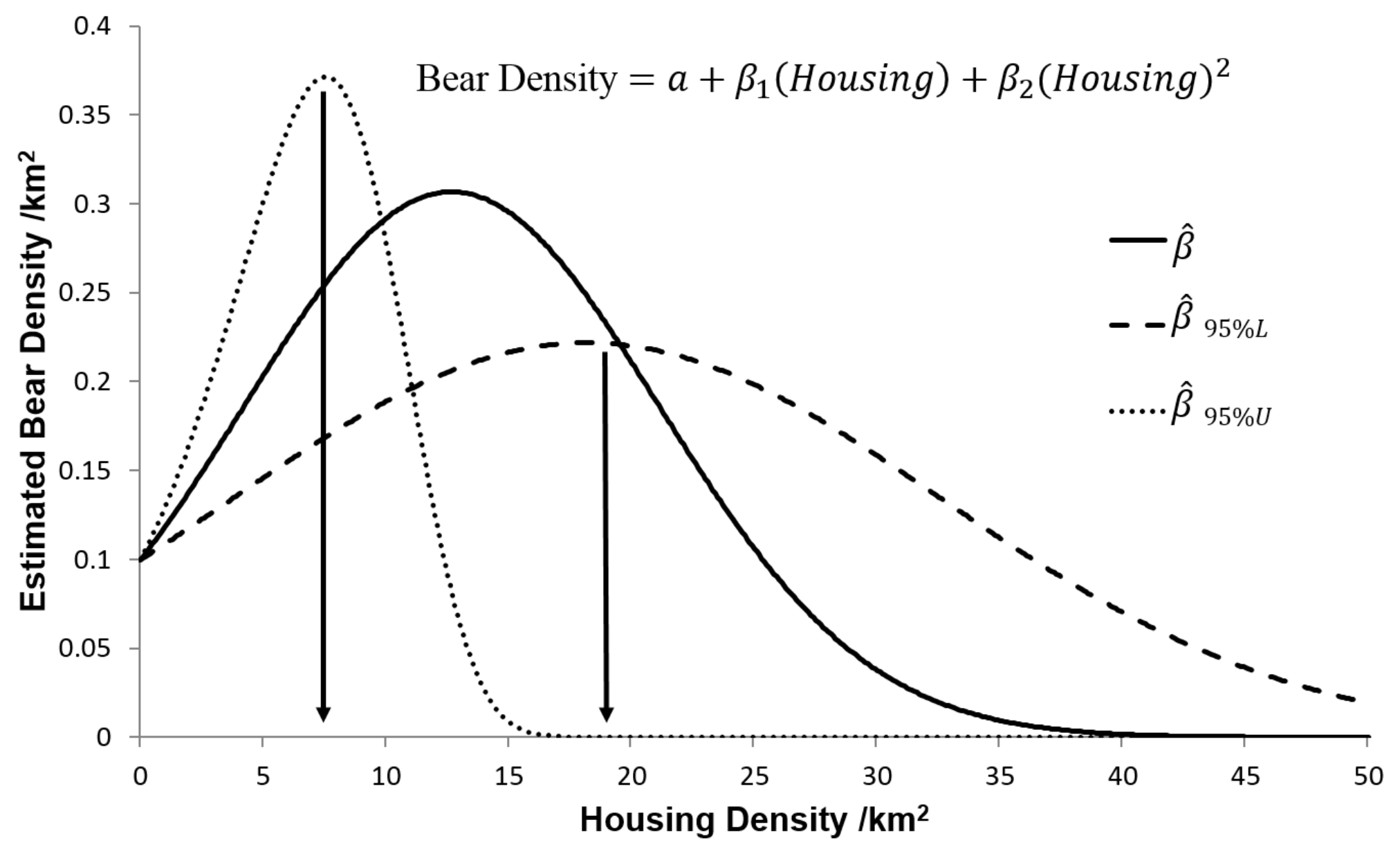

Fig. 4 Quadratic relationship between bear density and continuous housing density, as estimated by a spatial mark-recapture model of density as a linear function of housing density + (housing density) $)^{2}+$ latitude. Estimated values are at the average scaled latitude $(0)$ for the Combined study area. Dotted and dashed curves were calculated using the upper and lower bounds of the beta parameters for housing density and squared housing density, the maxima of which (arrows) are used to indicate a 95\% CI encompassing housing densities within which maximum bear density occurred $\left(7.5-18.2\right.$ houses $\left./ \mathrm{km}^{2}\right)$. 